\title{
GEOMORPHOSITES ASSESSMENT FOR THE DEVELOPMENT OF SCIENTIFIC GEO-TOURISM IN NORTH AND MIDDLE ANDAMAN'S, INDIA
}

\author{
Kavita ARORA* \\ University of Delhi, Shaheed Bhagat Singh College, Department of Geography, India, e-mail: kavitajnu07@gmail.com \\ Swati RAJPUT \\ University of Delhi, Shaheed Bhagat Singh College, Department of Geography, India, e-mail: swatisush@yahoo.com \\ Rashmi Rani ANAND \\ University of Delhi, Shaheed Bhagat Singh College, Department of Geography, India, e-mail: rashmiranianandjnu@gmail.com
}

\begin{abstract}
Citation: Arora, K., Rajput, S., \& Anand, R.R. (2020). GEOMORPHOSITES ASSESSMENT FOR THE DEVELOPMENT OF SCIENTIFIC GEO-TOURISM IN NORTH AND MIDDLE ANDAMAN'S, INDIA. GeoJournal of Tourism and Geosites, 32(4), 1244-1251. https://doi.org/10.30892/gtg.32408-564
\end{abstract}

\begin{abstract}
India possesses some of the most interesting, intriguing, wonderful landforms. The diversity of landforms in India arises from unique geology, structure, tectonic history, climate and coastline. India, therefore, provides a rich context for the study of diverse landforms and how they are influenced by the processes of the earth's surface. Their detailed mapping and visualization is yet to be done. Geomorphosites can potentially be major tourist attraction in India. On the one hand they are integral part of country's geological evolution and on the other, these sites consist of features that are often associated with events of cultural or religious significance. Geomorphosites as tourist attractions may yield a good revenue to the country and have a significant impact on the local community. They can also provide scientific understanding about the geological and geographic process to the researchers. Already people do visit these places but mainly for recreational purposes, therefore their tourism potential remains largely underdeveloped. Not much information is available regarding many geomorphosites in India. Specifically, detailed inventory of geomorphosites /geoheritage sites in India is important from the viewpoint of geo-tourism. Andaman and Nicobar Islands in India have the treasurer of different geomorphosites but at the same time they also known for its unique biodiversity and very fragile ecosystem therefore any type of tourism development require an understanding about the carrying capacity of different places and right aptitude about the fragility of the environment too. In this context present study examine few geomorphosites of Andaman and Nicobar islands by using the "Reynard Model" used by Reynard, 2008.
\end{abstract}

Key words: Geomorphosites, Geo-tourism, "Reynard Model”, carrying capacity, tourist perception

$* \quad * \quad * \quad * \quad * \quad *$

\section{INTRODUCTION}

India is perceived as magnificent landscape because of its unique geology, structure, and tectonic history. The diverse landforms in India have great influence on India's tourism. Now more and more people are visiting India than ever before. Around 2.4 million international tourists came to India in 2017 they were five times more than two decades back. Though the real boost is coming from domestic travel. In less than 10 years, the World Travel \& Tourism Council expects India to become the fourth-largest travel and tourism economy behind China, the U.S., and Germany. Tourism in the subcontinent generated more than $\$ 230$ billion in 2017, up from almost \$209 billion in 2016 (Popescu, 2018). The vast country offers myriad options. In India, tourism is steered by government subsidies and tax incentives, five regional budget airlines debuted100 far-flung routes last year, helping citizens' desire to explore.

However, unchecked growth can threaten stakeholders in the fragile places supported by the surge in visitors. Therefore India needs to follow the principles of geo-tourism. Geo-tourism is environmentally and culturally responsible tourism at the same time it is synergistic that means it bring together all elements of geographical character to create a travel experience that is richer than the sum of its parts and appealing to visitors with diverse interests. Geo-tourism is especially important in the case of Andaman and Nicobar Islands as the islands has fragile environment and already facing the challenges of biodiversity loss, damage of ecosystems, water scarcity, loss of indigenous people and seismicity (Moef, GOI/UNDP Action Plan, 2003).

\section{ANDAMAN AND NICOBAR ISLANDS: A HIGH POTENTIAL GEO-TOURIST DESTINATION IN INDIA}

The Andaman and Nicobar Islands, located in the Bay of Bengal to the east of the Indian mainland has several ingredients that can make it a favored tourist destination. There has been a rise in the arrival of tourists in Andaman and Nicobar islands after 2005. This has primarily been driven by domestic tourists. Although there also appears to be a marginal increase in the number of international tourists between 2005 and 2010, this has almost remained stagnated from 2010 to 2015. Andaman and Nicobar islands have recently became a very popular destination for the tourists the Figure 1 shows that the total tourist visits have increased from last two decades. There has been an increasing trend of tourist arrival since 1991, with some fluctuations around 2005. This can be attributed to the impact of tsunami that hit the coast in 2004. Since 2005 the numbers of international tourists have also shown an increasing trend. According to data available with the home ministry, more than 16 lakh tourists visited the Andaman and Nicobar Islands between 2015 and October 2018 to enjoy the natural beauty, beaches, flora and fauna and historically-significant landmarks in around 38 inhabited islands out of the 572 islets.

The archipelago has received 4, 023, 93 tourists, including 11,818 foreigners, till October, 2018 while it received 4, 87,229 tourists, including 15310 foreigners in 2017. In 2016, as many as 4, 00,019 tourists, including 15,467 foreigners, had visited the Andamans and in 2015 , a total of 3,11,358 tourists, including 14,674 foreigners, had gone to the union territory (Figure2).

The Andaman and Nicobar Islands is a union territory and comes under the administrative control of the home ministry of India. The main challenge of the islands is its isolation from the mainland. The Government of India has taken various measures to promote and develop

\footnotetext{
${ }^{*}$ Corresponding author
} 
the tourism activities in these islands. The government is promoting public-private partnership (PPP) for the development of tourism (Sharma, 2018). Foreign tourists can now directly fly to the Andaman and Nicobar Islands the government has designated Port Blair airport as an authorized immigration check post for entry into and exit from India with valid travel documents.

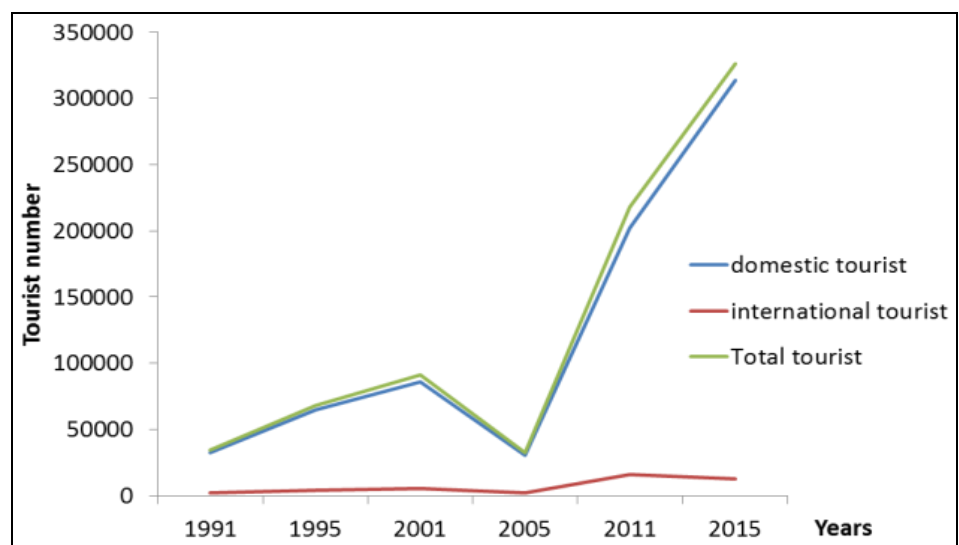

Figure 1. Tourist Arrivals in Andaman and Nicobar Islands, India (1991-2015)

(Source: Directorate of Economics and Statistics, A\&N Islands 2016.

Tsunami of 2004 had an impact on tourist visit in 2005)

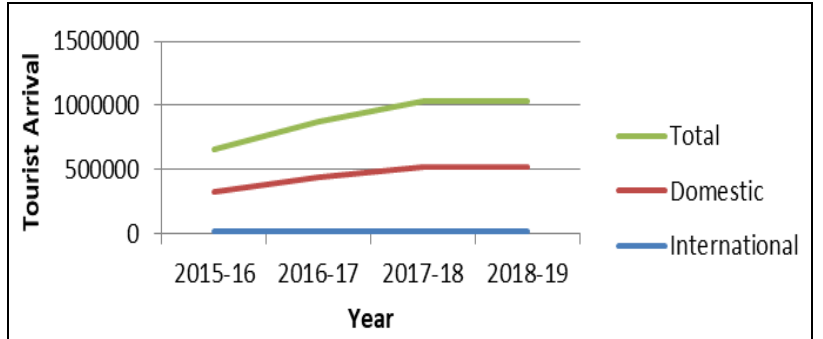

Figure 2. Tourist Arrival in Andaman and Nicobar Islands, India (2015-2019)

(Source: Directorate of Economics and Statistics, 2018)

In another notification, the home ministry appointed the Superintendent of Police, CID, the Andaman and Nicobar Police, as the "civil authority" for the immigration check post at Port Blair airport with effect from December 31, 2018 (Times of India,31-12- 2018). The efforts are also evident in promoting the sites as Geosites and heritage sites, promoting beach activities, opening hotels and providing the amenities for recreational purposes but lacking in tracing the value of these places as the sites of scientific tourism. Considering the carrying capacity of the places government also put restrictions on the numbers of tourists at some places. But public as well as private tourism development approaches both most of the time have missed the tourists opinion as an actor of the system and either based on the livelihood generation for the locals or revenue generation for the government. In this regard present study will provide first-hand information about the tourist's opinion and perception about the development of different geomorphosites. At the end study also present a detail discussion about the carrying capacity of these sites which need to be considered by the government and tourist agencies while promoting the tourism at these places.

OBJECTIVE: The objective of this paper is to evaluate selected Geomorphosites of Andaman islands for the Development of Scientific Geo Tourism.

STUDY AREA: The survey was carried in the following geomorphosites on Andman islands namely

1. Volcanic Origin: $\bullet$ Barren Island

- Mud Volcano. Baratang

2. Karst Topography $\bullet$ Limestone caves, Baratang (Figure 3).

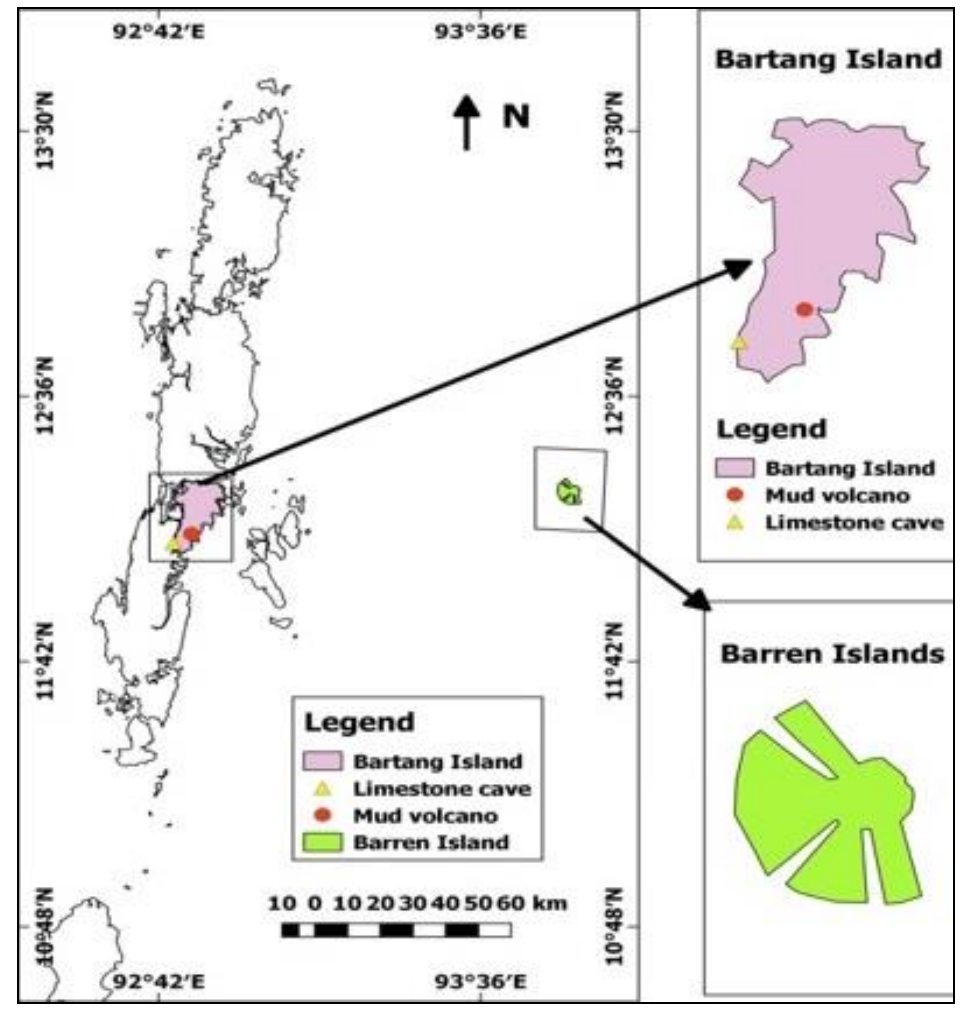

Figure 3. Location of Selected Geomorphosites at Andaman Islands, India 
The Barren Island (Figure 3) is a volcanic site studied to assess the potential site of scientific and volcano tourism. Rational behind choosing this site is that, it is relatively less studied and less known. This is the only active volcano of Indian territory. It is located $70 \mathrm{KM}$ east of the Andaman Island chains. It is uniquely positioned given that it is a place where oceanic volcanic and meta volcanic rocks, such as pillow basalts, ultramafics, serpentinites, greenstones, as well as flysh sediments are exposed (Allen et al., 2007).

However, Barren Island is a restricted zone and special permits are required to visit it. Also, one cannot stay in the island. Hence in order to experience the island, one needs to plan an early morning trip. It takes 4 to 5 hours to reach the island. Tourists enjoy travelling to the island just to get a proximate view of it. They travel through ships and get enthralled by the interesting basalt formations and topography shaped by past lava flows as well as fast growing coral gardens. The island can be visited by obtaining approval of the forest department as well as after getting the necessary permits. In 2018 the volcano has erupted and has drawn attention of tourists from around the world. The mud volcano and lime stone cave at Baratang Island are (Figure 3) other two important geomorphosites which are not yet explored for scientific purposes.

The Baratang island trip brings forward the tropical side of the Andaman Islands. It has dense Forest, Tribes, and Mangroves. Various recreational activities like Dongi rides, beaches, birds, caves and trekking etc also happens here. Baratang Island is about $90 \mathrm{~km}$ away from Port Blair. Regular bus services are available from STS Bus Terminal, Aberdeen Bazar. Journey takes about 2 hours and 30 minutes from Port Blair to Middle Strait. The journey is in 2 phases - Port.Blair to Jirkatang ( $40 \mathrm{~km}, 1 \mathrm{hr} 15$ minutes) and then Jirkatang to Baratang (49 km, 1 hr 15 minutes) From Jirkatang starts a stretch of 49 km forest (Jarwah Reserve Forest), where you cannot halt your vehicle or walk on foot or take snaps/video. On the other end of the Jarwah Reserve forest is Middle strait jetty. The jetty will take you to the other side of the strait in about 15 minutes and then you will reach Baratang islands. The site of Mud Volcano (Figure 4) at Baratang is about $4 \mathrm{~km}$ away from the jetty. To reach their shared taxi to and fro from Baratang can be hired.

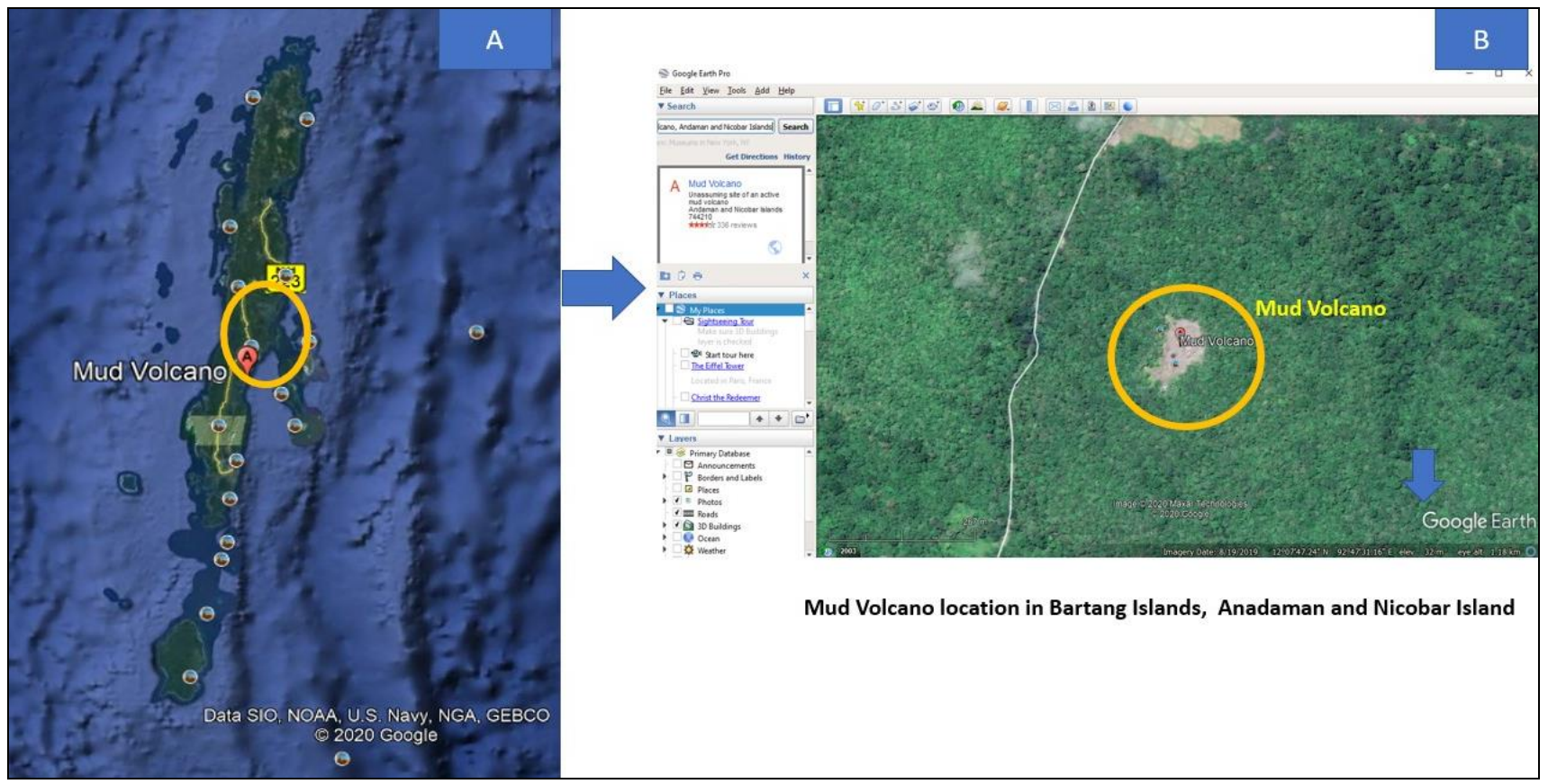

Figure 4. The Aerial View of Mud Volcano, Baratang, Andaman Islands (Source: Data SIO NOAA, US Navy, NGA, GEBCO, 2020; Google ) (A) Macro View of Mud Volcano (B) Meso View of Mud Volcano

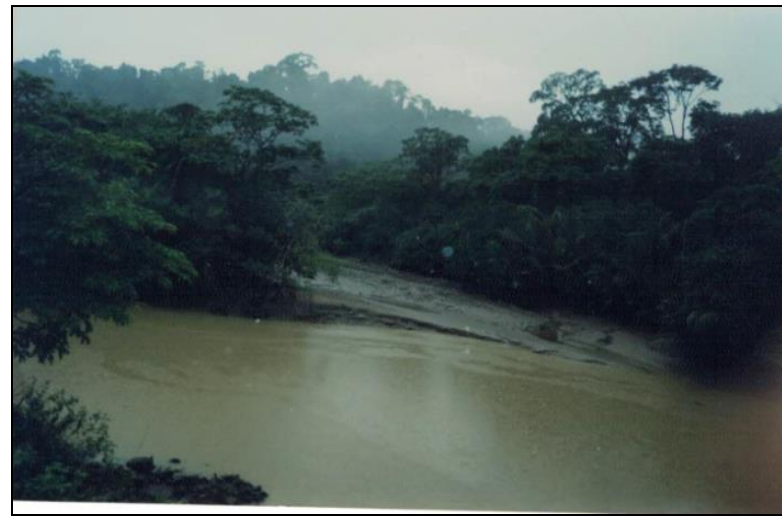

Figure 5. The Mud Volcano, Baratang, Andaman Islands

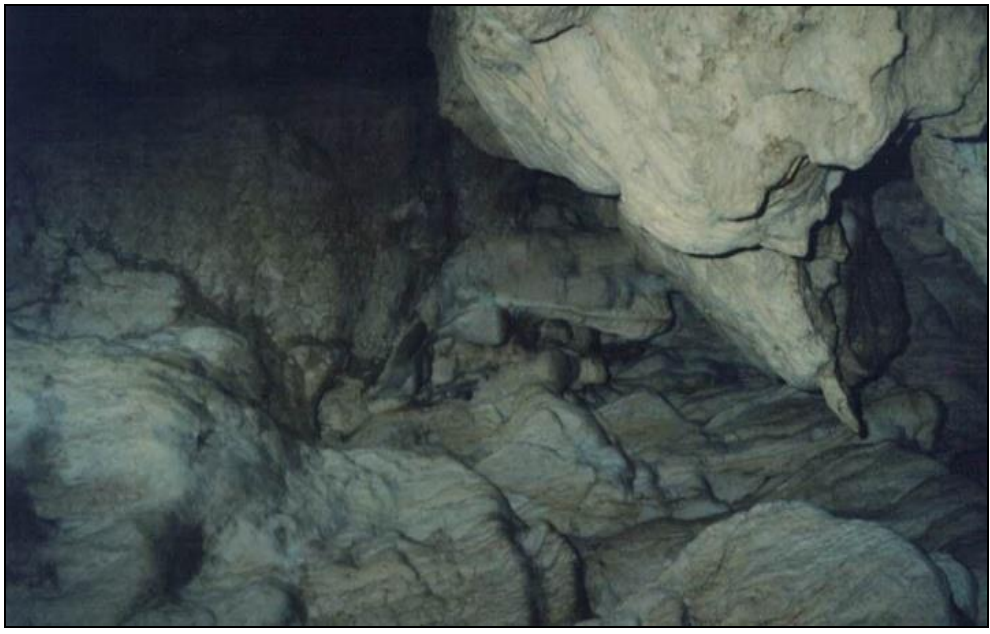

Figure 6. Limestone Caves, Baratang

Mud volcano is important geomorphological site as here volcanic activity is taking place due to the ongoing subduction of the Indian Plate beneath the Andaman island arc, which forces magma to rise in this locationof the Burma Plate (Balasubramanian, 2008). It is an interesting feature on the earth. It is a geological phenomena created by the extrusion of pressurized gases and mud from below the crust. 
A mud volcano tends to start out as small bulges and develop into cone like landforms. There are about 30 mud volcanoes in the Andaman Islands. A mud volcano may also erupt sprays of mineral water and sediments like mud or clay with or without oil (Balasubramanian, 2008). Deposition of miles thick sediments deposited on the ocean floor, the weight of which traps and heats up organic materials and creates fluids and gas in the sediments, building up regional level pressure and causing fluid and gasses to escape upward leads to the formation of tall, cone shaped mud volcanoes which may have crater on the summit.

Andaman and Nicobar islands also has various attractive locations to observe the different features of Karst Topography. Limestone cave near Baratang is one of them (Figure 6). The lime cave in Baratang island is located $100 \mathrm{~km}$ north of Port Blair and situated between the South and Middle Andaman (Lat. $12^{\circ} 05^{\prime} 44.2^{\prime \prime} \mathrm{N}$ and Long. $92^{\circ} 44^{\prime} 37.6^{\prime \prime} \mathrm{E}$ ). Limestones are sedimentary rocks and the limestone cave in Baratang would have formed over millions of years due to deposition of marine life, shells, corals and skeletons. This later on underwent a natural compression to form unique shapes within caves. The limestone caves of Baratang Island also contain speleothems. Dripstone curtains a meter or more in length are seen hanging from the ceiling, and pillars of stalagmites grow above the ground Radiocarbon dating (Laskar et al., 2013). The caves stalactites and stalagmites embrace the secret of a million years of Andaman.Some of the structures that can be seen in the limestone caves of Baratang are speleothem, flowstones, stalactite, stalagmites and columns.

Geologistand biologist (Whitton and Potts, 2000; Knoll, 2008; Swingley et al., 2008; Biello, 2009; Blankenship, 2010; Brasier et al., 2015) indicates that these limestone structure form around 3.8 billion years ago when the most primitive life forms evolved in the oceans. The single celled algae called cyanobacteria performed photosynthesis, releasing oxygen into the air. There were many other chemical reactions performed by these algae which resulted in the formation of dolomitic limestone - a sedimentary rock. During this time, the acidic groundwater or underground rivers dissolved some of the limestone leaving cavities behind. Eventually, due the movement in the earth's crust, these became exposed to dry land. As time passed, the weak carbonic acid in rainwater dissolved and continued to erode the limestone formations to give it various shapes and structures (Andaman Islands Destination Guide).

\section{MATERIAL AND METHODS}

The methodology adopted in the paper is both qualitative and quantitative techniques. Three most visited sites, which have also geomorphological significance were selected as the geosites in North and Middle Andamans. Then after, geomorphosites tourism perception study was done and was evaluated on the basis of scientific, educational, economical and conservation values through Structured and semi structured questionnaire. The data collected is a longitudinal data. The tourists have been questioned regarding various values of these sites like scientific, educational, economical and conservation values. The sample of 50 tourists has been randomly selected. The care has been taken to ascertain response from both national and international tourist. The survey has been carried in November 2019 at geomorphosites namely Barren Island, Mud Volcano and Limestone caves at Baratang.

Tourism potentials are evaluated using "Reynard Model" (Reynard, 2008) whereby selected sites in North and Middle Andamans were fitted into "Reynard Model". The criteria of "Reynard Model" (Figure 7) have been applied to assess the perception of the tourists related to each geomorphosite. The perception is an important factor to assess in a tourism system as tourist is an actor of the system, without his movement the activity of tourism will lose its significance.

Reynard et al. (2003) analyzed the relationship between geomorphology and tourism: geomorphology may be a tourist resource as part of the primary or original offer (geomorphological site as an attraction or geomorphological site as a support for tourist activity, e. g. climbing) and secondary or derived offer, when tourist infrastructures (e.g. didactic trails), instruments (e.g. educational booklets) or services (e.g. guided tours) are proposed for effective use of the original offer (Kulbalikova, 2013).

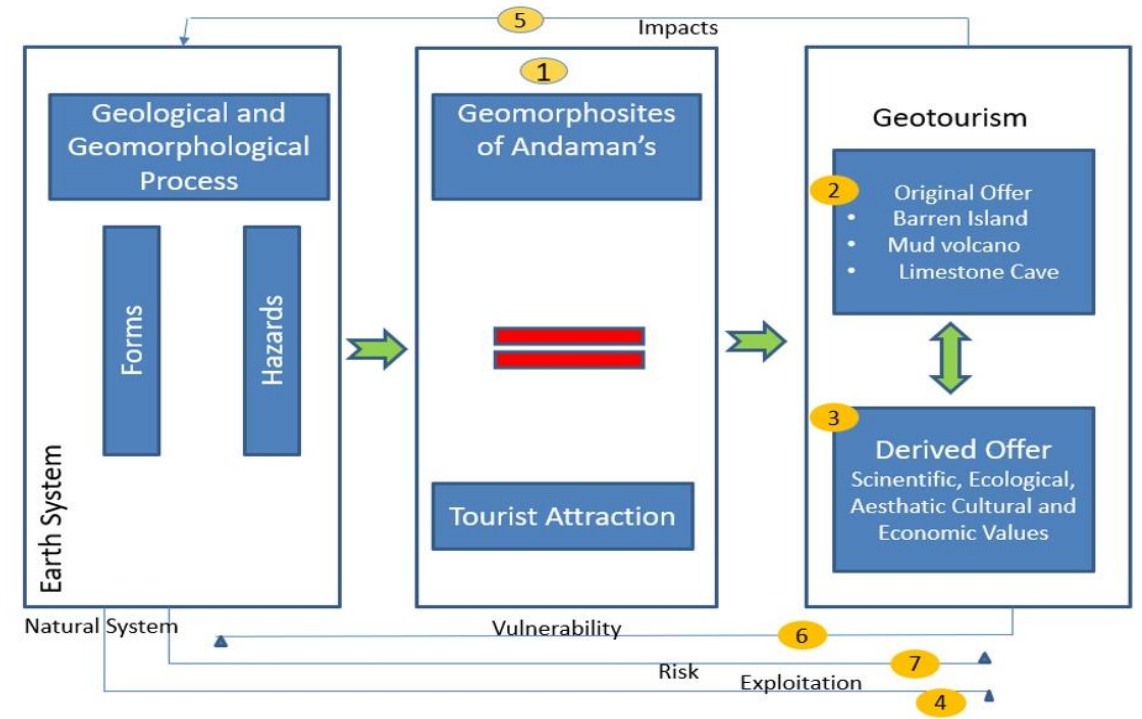

Figure 7. "Reynard Model" for Scientific Research and Tourist Promotion of Geomorphological Heritage (Source: Reynard, 2008; modified by authors)

"Reynard Model" (2008) is an important factor in the holistic approach for sustainable tourism development (Reynard and Brilha, 2018). "Reynard Model" (2008) investigates the role of tourism and its effects on the development of geomorphosites and tourism potentials of any identified site. Reynard in his 2008 model analyzed the relationship between geomorphology and tourism. For any geomorphologic site, geomorphology and geology is the original offer. This model includes plenty of assessment methods for evaluation of geosites and geomorphosites from different points of view. The analysis on scientific value, added value and compound value of the research location gives it new perception to look tourism and its scope. In this study "Reynard Model" (2008) is used to analyzed the potential of scientific research and geotourism development at three selected sites of Andaman Islands, India

The importance of geodiversity can be represented by multiple values that are important for human activities (Gray, 2004):

- Scientific value: It deals with knowledge of geology and geomorphology of the region. The region must have evolved 
geologically to form the present structure but the structures are bound to be dynamic and might change to new forms in future. The geomorphosites thus have huge scientific value. Like a volcanic site can be scientifically explored to understand the behaviour of the volcano, the features formed by it and its future processes.

- Cultural value is connected to geomythology - an explanation of the geological and Geo-morphological features using the supernatural forces and beings (Vitaliano, 2007). Cultural values are also attached to amenities and accessibility factors. The development process and the availability of amenities are big boost to the tourism activity of any area.

- Aesthetic value refers to visual (and non-visual) appeal provided by geo-diversity including a psychological impact on human beings (Gray, 2004; Pereira, 2006). The geomorphosites have an aesthetic importance as they become a natural area with natural settings. Many tourists appreciate the natural beauty and biodiversity of such sites. But aesthetic significance is very subjective.

- Ecological Value: These areas have lot of biodiversity both in terms of flora and fauna. The regions are many a times preserved and conserved by the state to maintain or enhance the ecological value of the area.

- Economic and functional value is represented by the use of resources, e. g. fuels, construction materials; utilization of landforms, e. g. platforms as a suitable place for airports (Gray, 2004) and utilization of geodiversity, respectively geoheritage, for geotouristic and geoeducational activities (Reynard et al., 2003; Pralong, 2003; Panizza and Piacente, 2008). The tourism activities also provide various job opportunities in isolated geosites but they are usually seasonal in nature.

Value Criteria of Assessing Geomorphosites for the Development of Scientific Geo-tourism

Assessment in this study is based on the modified value criteria suggested by Reynard et al. (2007)

Scientific value

Geological/ geomorphological significance

Knowledge of Geomorphological and geological process and phenomena

Ecological value

Ecological significance

Knowledge of the ecosystem

Aesthetic values

Understanding the natural beauty

Appreciating aesthetic values in geosites

Cultural value

Geomythology and religious value

Educational importance

Glimpses of diverse Indian culture

Economic and functional value

Economic products

Job opportunities (Reynard et al., 2007)

The respondents have been asked to rate the significance of selected geomorphosites based on the "Value Criteria", on the scale of 0 to 1 . Their responses have been tabulated to assess the value significance of each site i.e. which site is more valuable for which criteria namely, scientific, ecological, research, cultural or economic. Average scores of each sites based on scores given by tourist is calculated and proportion based linear scale index was prepared. The after, obtained value was categorized into: Very high $=1-0.8 ;$ High $=0.8-0.6 ;$ Medium $0.6-0.4 ;$ Low $=0.4-0.2$; Very Low $<0.2$.

\section{RESULTS AND DISCUSSION}

A primary survey was conducted in Novemeber 2019 among the visitors of Barren Islands and response were collected from 50 tourist of various age groups. The respondents male and female ratio was $50: 50$. On the basis of their responses following table is drived for this site (Table 1).

Table 1. Assessing the Barren Island Volcanic Sites

\begin{tabular}{|l|c|c|}
\hline Value & Rating of Respondents & Degree of Geotourism Relevance \\
\hline Scientific & 0.9 & Very high \\
\hline Ecological & 0.9 & Very high \\
\hline Aesthetic & 0.7 & Medium \\
\hline Cultural & 0.6 & Medium \\
\hline Economic & 0.5 & Meduim \\
\hline
\end{tabular}

Table 1 shows that most of the tourist rated that this site is very significant for the pupropse of scientific research but no where it is highligted in tourism promoton of the islands. According to respondants scientifically and ecologically this site is very important but aesthetically ,culturally and economically they rated it in the medium level which shows that site has potential to develop the geotourism. Many visitor come here to have experience of viewing an active Mud volcano which demonstrate the power and importance of fire. According to Hindu mythology 'Agni' is a Sanskrit word meaning fire and connotes the Vedic fire god of Hinduism There were many fires discussed in Vedic times. One of the fire among them is located under the sea, spat out by a submarine mare known as Vadavagini that causes mists and clouds to form. This fire of the submarine mare prevents the sea from overflowing. But one day, it will escape and burst forth as volcanoes. That day will be Pralaya - the sea will overflow and consume the earth. Therefore this site also has geomythological value but it is not much explored. The educational value is also underutilized therefore visitors culturally ranked this site at medium level.

The journey to volcano site can be made more attractive and research oriented and economically gainful by advertising its significance, providing the facility of experts guides and using the pamphlets etc. The volcano is of late Pleistocene period and lava flow is dominantly basalt and basaltic andesite, with minor andesite (Sheth et al., 2009) which made the site more attractive for scientific geo-tourism .The volcanoes have equally excited the academics and the adventure seeker. While academics are interested in studying volcanicity, volcanic eruptive style and plate tectonics, the adventurous tourists seek the thrill of volcano boarding and taking hot air balloon trips over volcanic landforms. It is not surprising that volcano related sites attract thousands of tourists. The Barren Island site has all the ingredients of becoming a very popular tourist attraction.

On the site of Mud Volcano also almost similar responses are received during the November 2019 survey of tourists (Table 2). Here also most of the visitors had the opinion that site is very important for scientific studies and educational purposes but the level of maintenance and 
its right promotion was unsatisfactory. Most of the tourists perceived that this site is very crucial for research in the area of plate tectonic and can provide great insight to the earthquakes and tsunami related research they also had the opinion that site also possess unique biodiversity and has high ecological value. Most of the tourist had opinioned that the site has medium aesthetic value and can be improved significantly by maintenance and by small human interventions like making the attractive boundary and labeling of the places. The place has very less amenities which can be improved. This site got low rating in the context of travel, boarding and lodging facilities. Though the site is carrying the geomythological and religious values but they are still unexplored. The site is the symbol of truly dynamic geology but it isnot utilize properly for educational purposes therefore most of the visitors culturally mark it at medium level

Table 2. Assessing the Mud Volcano Site

\begin{tabular}{|l|c|c|}
\hline Value & Rating of Respondents & Degree of Geotourism Relevance \\
\hline Scientific & 0.9 & Very high \\
\hline Ecological & 0.3 & High \\
\hline Aesthetic & 0.7 & Medium \\
\hline Cultural & 0.6 & Medium \\
\hline Economic & 0.3 & Low \\
\hline
\end{tabular}

Both the sites has incredible potential to increase scientific tourism however "Reynard Model" warns us that unchecked exploitation of geosites can magnify their vulnerability risks and lead to tremendous losses. The figure below (Figure 8) explains that by introducing a derived offer in the form of education and research, the propensity of unregulated tourism in geoheritage and geosites to cause harm to the natural system and add to natural hazards can be reduced for geomorphosites of volcanic origin.

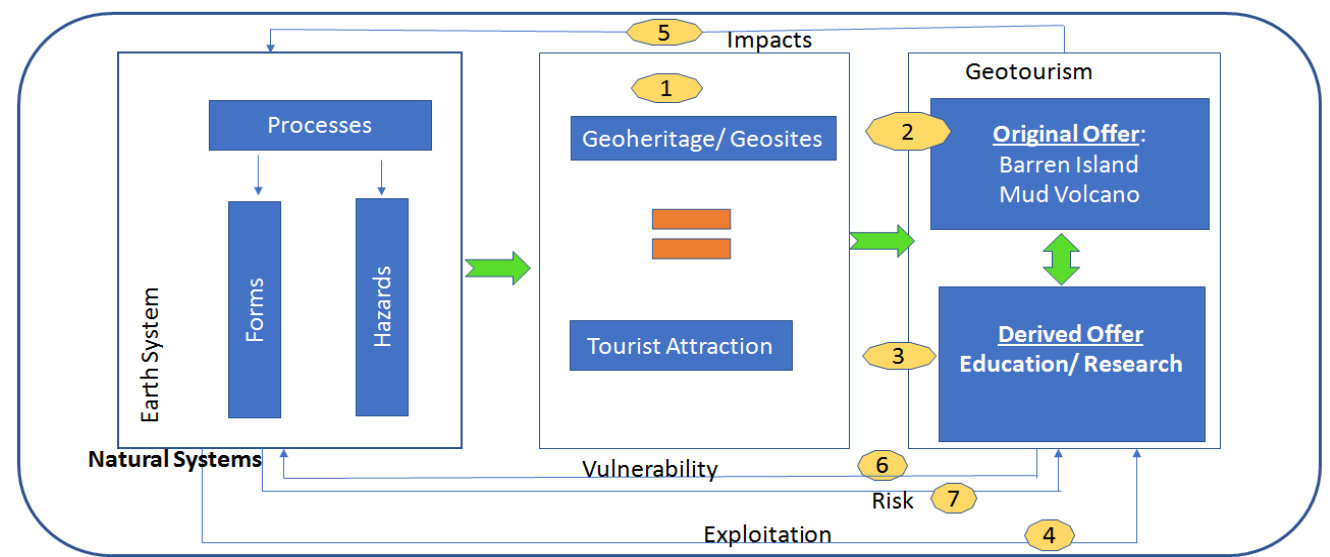

Figure 8. "Reynard Model” for Geomorphosites of Volcanic Origin (Source: Reynard, 2008, 225-230; modified by authors)

During the survey at Limestone cave visitors have the opinion that Lime Stone Caves Karstland is very important site for scientific research and study. The study of site can unfold the history of over millions of year's deposition of marine life, shells, corals and skeletons (Palmer, 1991). The tourist also had the opinion that sight is surrounded by variety of mangroves and other flora therefore has high ecological value. The site and journey from Baratang to limestone cave provide beautiful picturesque views therefore aes thetically also it rated high by the visitors. During the survey perception of the people was that this site has high culture value but economic value found to be low and need to be improved significantly (Table 3). The cave are geomythologically very important because the stalagmite formations present in most natural limestone caves resemble Shiva Linga, a representation of Hindu God Shiva, due to which some of the caves in India are considered of religious importance. The limestone caves of Baratang do have a significant pattern of various god like images formed out of those reactions which are worth seeing by the visitors and give out an impression of the ancient but rare and extinct sculptures combined to produce a magnificent yet spectacular designs each one bearing some divinity and lightening element. The population of Baratang islands consist Bengalis, Telgu, Tamils, Malyalis which provide the glimpses of mini India. A visitor can also see the ethnic culture of Munda, Khadiya, and Chotanagpuri. There is no opulent restaurant in Bartang Island, but a visitor surely gets to experience the rich taste of this island through its food stalls and small eateries. Most of these eat eries are located around Nilambur jetty and they mainly serve Bengali and South Indian cuisines.

Table 3. Assessing the Limestone Caves at Baratang

\begin{tabular}{|l|c|c|}
\hline Value & Rating of Respondents & Degree of Geotourism Relevance \\
\hline Scientific & 0.9 & Very high \\
\hline Ecological & 0.9 & Very High \\
\hline Aesthetic & 0.8 & High \\
\hline Cultural & 0.8 & High \\
\hline Economic & 0.3 & Low \\
\hline
\end{tabular}

According to "Reynard Model" the figure below (Figure 9) shows that, karst topography and karst aquifers, potentially provides education and research as a derived offer in the field of karst hydrogeology, karst modeling, karst hazards and management. Karst areas are important to study but because of slow work of dissolution by water with limestone rocks making it a peculiar and vulnerable environment. Therefore only limited scientific and research oriented tourism may be promoted on this site.

The tourists visiting all the sites perceived that these areas have very high scientific value. These sites are store house of knowledge especially indigenous knowledge. The ecological values were high but aesthetic values were of medium relevance. It was found the tourist perceive that the sites has medium cultural and low economic value. This is because the amenities like hotels, roads etc were not much available and the area could not create much of the economic opportunities too. 


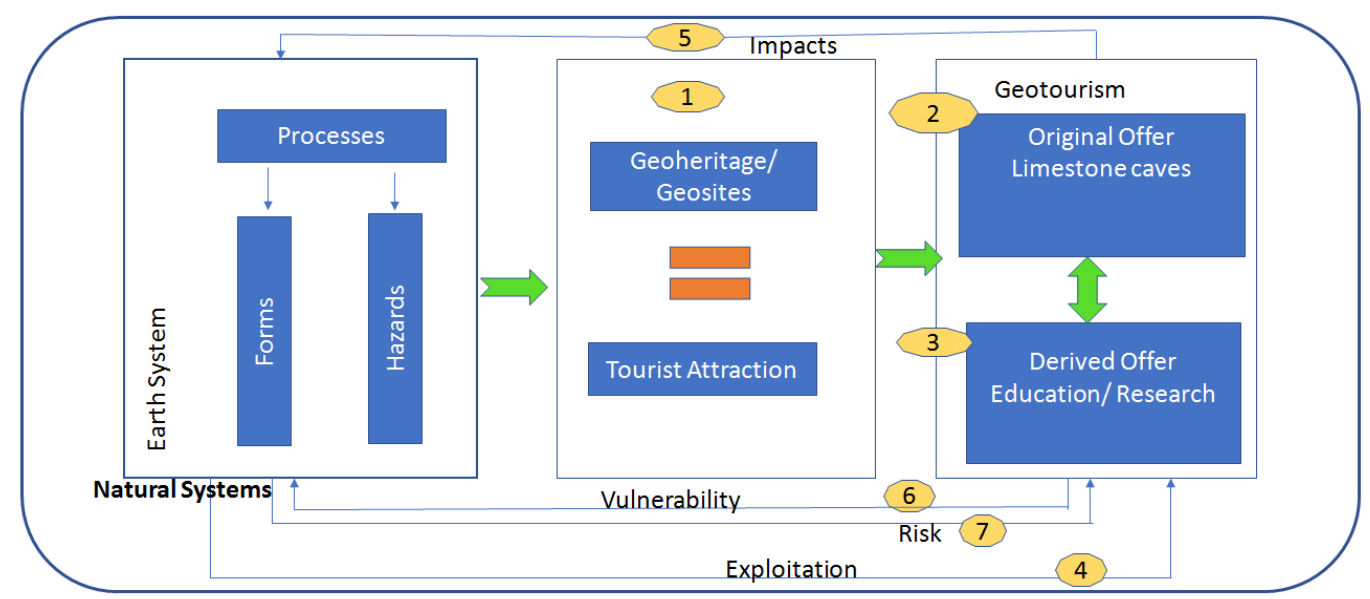

Figure 9. "Reynard Model” Geomorphosites of Karst Topography (Source: Reynard, 2008, 225-230; modified by authors)

\section{CARRYING CAPACITY OF THE SITES}

These sites has great scientific value but at the same time they have very fragile ecology, they cannot bear the outside influence after a limit therefore while promoting the tourism at these sites a special care about their carrying capacity need to be consider ed. The islands are fragile not only physically, environmentally, strategically but also socio-economically. In 2013 R. Gobalakrishnan, K. Sivakumar and L. Kannan from Centre of Advance Study in Marine Biology, Faculty of Marine Sciences, Tamilnadu done a study of Human Impact on the Limestone Cave, Baratang Island in the Andamans found the lint deposition that visitors might leave behind a mix of biodegradable and non-biodegradable materials, can create microhabitats with nutrients that can support the growth of contaminating microbes and can alter even the underlying surface They indicated that changes in the cave's microclimatic conditions such as temperature, CO, relative humidity and microbial composition besides abundance are associated with human interference. These changes can damage the cave features and artefacts, the very factors that attract the tourists. Hence, there is an increasing need to investigate the microorganisms of the caves, determine their reservoirs and create awareness among the public about the importance of caves in the island ecosystems and the necessity to conserve them and keep them clean (Gobalakrishnan et al., 2013). The eco-diversity and richness of A\&N are its core strength. Any development activity in the islands including tourism has to be sensitive to their fragility.

Mangrove forests are found on shores, mouths of creeks and inland channels of these islands and occupy 966 sq.km areas. Mangroves add to lush natural landscape of the islands, making creek cruises a creek a popular tourist attraction. The journey from Baratang to lime stone caves by small boats provide a mesmerizing view of mangroves to the tourists. The unique and rich mangrove environment present in Andaman \& Nicobar has been the focus of substantial research. Concerns were raised about the decreasing quantum of mangrove forests (mangrove forests were destroyed to make land available to settlers, the wood also finds use as fuel wood, construction material and charcoal). Tourism development along the creeks can poses a threat in the form of clearance of forests for developing resorts, jetties etc. However, with the strict monitoring by the administration this can be controlled.

There are valid concerns regarding the status of forest in Andman and Nicobar. There is evidence that forest land has been cleared by encroachers and unscrupulous players in the tourism industry. This has resulted in loss of forest cover and has caused harm to the wildlife. Unregulated tourism clearly poses threat to the natural environment. Therefore the tourism development strategy of Andman and Nicobar needs to be forest focused - tourism promotion along with preservation of the natural environment. A key requirement for this is that the tourism related infrastructure should be developed in the peripheral area which lies outside the forest area. There is also a need to promote activity based tourism, related to natural trails, bird and wildlife watching, and research. The core forest area should be accessible only to the serious researcher. For facilitating this kind of work, a buffer area between the periphery and the core forest area can be used to create temporary and mobile infrastructure such as tents, machan over trees, temporary hutments etc.

While developing the tourism in these areas. The dwindling population of the tribals is another source of concern. Because of their uniqueness, the tribal population in $\mathrm{A} \& \mathrm{~N}$ is a subject of curiosity and kindles tourist interest. Like in a journey from Port Blaire to Baratang a stretch of $49 \mathrm{~km}$ forest from Jirkatang starts which pass through Jarwah Reserve Forest. Watching the tribals from buses and cars may be a tourist attraction for visitors but various reports in the past highlighted the numerous harmful impact of tour ism on the tribals in this area. Tourism could negatively impact tribal lifestyle if tribal areas are freely opened and tribal practices put on display.

Availability of land for infrastructure development is limited as more than $92 \%$ of the land is under forest cover (most of which are protected / reserve). For example Baratang island where mud volcano and limestone caves are located has total area 297.60 sqkm, from which $283.20 \mathrm{sq} \mathrm{km}$ is reserved forest area and only $14.40 \mathrm{sq} \mathrm{km}$ area is available for other uses. The Andaman and Nicobar islands are also among the most seismically active zones in the world, with earthquakes occurring even twice a month. Therefore infrastructure development at high scale in these islands can increase the vulnerability of the areas. Then there is the issue of the economics of providing for the everyday essentials of the people in Andaman and Nicobar. The islands depend on the Indian mainland for a majority of daily essentials necessary for daily existence. In places outside Port Blair, supplies are refreshed at a frequency of a week or more, and they need to be rationed. The local population is dependent on these supplies as are the tourists. An unregulated and very large influx of tourists can cause shortages and push prices up, thereby increasing the cost of living of the local population. Therefore tourism management agencies and government while promoting the scientific tourism at these sites should take care the fragility and carrying capacity of the areas.

\section{CONCLUSION}

Considering the limited carrying capacity and fragility of the islands a restricted size of tourism sector can be sustained here however Andamans can be made centre of geo heritage destination of India. Considering our analysis and evaluation, we propose that strong promotion of scientific tourism for the geomorphosites discussed here should be undertaken.

The geomorphosites are rapidly changing under dynamic conditions. Management of Geomorphosite should be an important aspect of geotourism in India. There can be possibility of formation of geomorphosites tourist circuit. There can also be establishment of 
interpretation centers in the docks carrying tourists to sites such as Barren Island, which can provide preview of the geomor phosite. Knowledgeable and well informed guides are needed especially at geomorphosites. Local people can also be helpful in imparting indigenous knowledgeto the tourist. The provision of information about geomorphological processes to tourists in simple language should be promoted. Geomorphosite tourism offers an opportunity to learn, and to enrich humanity. Hence, it can be stated that maintenance, conservation and preservation of geomorphosites should be seen as a project of national importance.

\section{REFERENCES}

Balasubramanian, A. (2008). The Andaman's Mud Volcanoes, Centre For Advanced Studies In Earth Science University of Mysore, Technical Report, 1 (Online Web), Accessed $31^{\text {st }}$ Dec 2019. https://www.researchgate.net/publication/313799816

Biello, D. (2009). The Origin of Oxygen in Earth's Atmosphere, Scientific American a Division of Springer Nature America, Inc. https://www. scientificamerican.com/article/origin-of-oxygen-in-atmosphere/

Blankenship, R.E. (2010). Early Evolution of Photosynthesis. American Society of Plant Biologists, 154(2), 434-438. https://doi.org/ 10.1104/pp.110.161687.

Brasier, M.D., Antcliffe, .J, Saunders, M., \& Wacey, D. (2015). Changing the picture of Earth's earliest fossils (3.5-1.9 Ga) with new approaches and new discoveries. Proceedings of the National Academy of Sciences of the United States of America, 112(16), 4859-4864, https://doi.org/10.1073/pnas.1405338111.

Carter, A.R., Najman, Y., Bandopadhyay, P.C., Chapman, H.J., Bickle, M.J., Garzanti, E., Vezzoli, G., Andò, S., Foster, G.L., \& Gerring, C. (2007). New constraints on the sedimentation and uplift history of the Andaman-Nicobar accretionary prism, South Andaman Island. In the Draut A, Clift PD, Scholl DW (Eds) Formation and applications of the sedimentary record in arc collision zones. Geological Society of America, Special Paper. 436, 223-254. https:// www.lancaster. ac.uk/staff/najman/Allen\%20et\%20al\%202008.pdf.

Chauhan, N. (2018). Foreigners can fly Directly to Andaman Now. Times of India. (Online Web), Accessed 16 ${ }^{\text {th }}$ December 2019, https://timesofindia indiatimes.com/india/foreigners-can-fly-directly-to-andamans-now/articleshow/67325549.cms

Gobalakrishnan, R., Sivakumar, K. \& Kannan, L. (2013). Human impact on the limestone cave, Baratang Island, the Andamans. Coastal Ecosystems of India In Kathiresan, K. and Ajmal Khan S. (Eds.) ENVIS, 203 CAS in Marine Biology, Faculty of Marine Sciences, Annamalai University, ENVIS Publication Series 1, p. 137-140.

Gray, M. (2004). Geodiversity: Valuing and Conserving Abiotic Nature. $2^{\text {nd }}$ Edition, John Wiley \& Sons Ltd. https://doi.org/10.1002/jqs.859.

Knoll, A.H. (2008). Cyanobacteria and Earth History. In the Antonia Herrero and Enrique Flores (eds), Cyanobacteria: Molecular Biology, Genomics and Evolution. Caister Academic Press, U.K. Retrieved from https://www.caister.com/cyan

Kubalíková, L. (2013). Geomorphosite assessment for geotourism purposes. Czech Journal of Tourism, 2(2), 80-104. https://doi.org/10.2478/cjot-2013-0005

Laskar, A.H., Yadava, M.G., Ramesh, R., Polyak, V.J. \& Asmerom, Y. (2013). A 4 kyr stalagmite oxygen isotopic record of the past Indian Summer Monsoon in the Andaman Islands. Geochemical Geophysical Geosystems, 14, 3555-3566. https:// doi.org/10.1002/ggge.20203

Palmer, A.N. (1991). Origin and morphology of limestone caves. Geological Society of America Bulletin, 103(1), 1-21, https://doi.org/10.1130/00167606(1991) 103<0001:OAMOLC >2.3.CO;2.

Panizza, M., \& Piacente, S. (2008). Geomorphosites and geotourism. Revista Geográfica Acadêmica, 2(1), 5-9, Retrieved from https://www.researchgate.net/ publication/26518748_Geomorphosites_and_Geotourism

Pereira, P. (2006). Património geomorfológico: conceptualização, avaliação e divulgação. Aplicação ao Parque Natural de Montesinho. [Geomorphological heritage: concept, assessment and promotion. Application in the Montesinho Natural Park]. Doctoral dissertation, Braga: University of Minho (In Portuguese), Retrieved from file:///C:/Users/john\%20pc/Downloads/2006_Pereira_PhD\%20(1).pdf

Popescu, A. (2018). Tourism in India is booming. But why is everyone so worried? 5.7. (Online Web), Accessed 20 ${ }^{\text {th }}$ December 2019, Retrieved from https://www.bloomberg.com/news/articles/2018-07-06/tourism-in-india-is- booming-so-why-is- everyone-so-worried

Pralong, J.P. (2003). Valorisation et vulgarisation des sciences de la Terre: les concepts de temps et d'espace. [Development and scientific popularization of earth science: the concept of time and space] In Reynard, E., Holzmann, C., Guex, D., \& Summermatter, N. (Eds.), Géomorphologie et tourisme, Actes de la Réunionannuelle de la Société Suisse de Géomorphologie (SSGm) 21-23 septembre 2001, Travaux et Recherches nº 24, Finhaut, Lausanne: Institut de Géographie (Geomorphology and tourism, proceeding of the annual meeting of Switzerland society of Geomorphology, Finhaunt, 21-23 September 2001), 115-127, Retrieved from https://www.unil.ch/files/live/sites/igd/files/shared/recherche/Article_TR_Pralong.pdf. (In French).

Reynard, E. (2008). Scientific Research and Tourist Promotion of Geomorphological Heritage, Supplementi di Geografia Fisica e Dinamica Quaternaria, 31 , 225-230, Retrived from http://www.glaciologia.it/wp- content/uploads/FullText/full_text_31_2/18_Reynard_225_230.pdf

Reynard, E., \& Brilha, J. (2018). Geoheritage: Assessment, Protection, and Managemen., Elsevier, Publisher: Candice Janco, ISBN: 978-0-12-80953.

Reynard, E., Fontana, G., Kozlik, L., \& Scapozza, C. (2007). A method for assessing the scientific and additional values of geomorphosites. Geographica Helvetica, 62(3), 148-158. Retrieved from https://gh.copernicus.org/articles/62/148/2007/gh-62-148-2007.pdf

Reynard, E., Holzmabb, C., \& Guex, D. (2003). Géomorphologie et tourisme: quelles relations? [Geomorphology and tourism: how are they related?]. in Reynard, E., Holzmann, C., Guex, D., \& Summermatter, N. (Eds) Géomorphologie et tourisme, Travaux et Recherches $\mathrm{n}^{\circ} 24$, Lausanne, Institut de Géographie, 1-10 Retrieved from https://serval.unil.ch/resource/serval:BIB_27034.P001/REF.pdf. (In French).

Sharma, Y.S. (2018). Government set to invite private companies for making India's islands world class tourist hubs. The Economic Times, (Online Web), Accessed $15^{\text {th }}$ December 2019, Retrieved from https://economictimes.indiatimes.com/industry/services/travel/government-set-to-invite-private-playersfor-making-indias-islands-world-class-tourist-hubs/articleshow/65964179.cms?from=mdr

Sheth, H.C., Ray, J.S., Bhutani, R., Kumar, A., \& Smitha, R.S. (2009). Volcanology and eruptive styles of Barren Island: an active mafic stratovolcano in the Andaman Sea, NE Indian Ocean, Bulletin of Volcanology, 71,1021-1039, https://doi.org/10.1007/s00445-009-0280-z.

Vitaliano, C. J. (2007). Geomythology, In the Piccardi, L., \& Masse, W. B. (Ed.), Myth and Geology. London, Geological Society.

Wesley, D.S., Min, C., Patricia, C.C., Amber, L.C., Liza, C.D., Jicheng, H., Barbara, M.H., Lauren, E.K., Ahmet, K., Surobhi, L., Stephen, D.M., Hideaki, M., Lawrence, P., Pushpa, R., Soichirou, S., Sattley, W.M., Yuichiro, S., Heather, L.T., Tatsuya, T., Tohru, T.Zi., Jason, R., Mamoru, M., Robert, E., \& Jeffrey, W.T. (2008). Niche adaptation and genome expansion in the chlorophyll d-producing cyanobacterium Acaryochloris marina. Proceedings of the National Academy of Sciences 105(6), 2005-10 https://doi.org/10.1073/pnas.0709772105

Whitton, B.A. \& Potts, M. (2000). The ecology of cyanobacteria: their diversity in time and space (Eds). Kluwer Academic Publishers, Dordrecht, 1-10, Retrieved from https://www.researchgate.net/publication/284603746_Introduction_to_the_cyanobacteria_in_the_Ecology_of_Cyanobacteria_Their_Diversity in_Time_and_Space_Eds_B/link/5662004008ae15e746

*** Andaman Islands Destination Guide (n.d). All you want to know about the Lime Stone Caves Andaman to [Blog Post]. Retrieved from https://andamanholidays.com/blog/andaman-activities/limestone-caves-andaman/

*** Directorate of Economics and Statistics, A\&N Islands (2016). (Online Web), Accessed $17^{\text {th }}$ December 2019, Retrieved from www.andamantourism.gov.in

*** Directorate of Economics and Statistics, A\&N Islands (2018). (Online Web), Accessed $17^{\text {th }}$ December 2019, Retrieved from www.andamantourism.gov.in

*** Moef, GOI/UNDP Action Plan (2003). India Andaman And Nicobar Islands Union Territory Biodiversity Strategy And Action Plan, Andaman \& Nicobar Islands Environmental Team, 2-90 Retrieved from https://kalpavriksh.org/wp-content/uploads/2019/05/Andamans-Final.pdf 